Int. Archs Allergy appl. Immun. 1977;55:I-VI

\title{
Contents, Vol. 55, 1977
}

I. Chemistry of Antigens and Antibodies. Antigen-Antibody Reactions

Løwenstein, H.; Aukrust, L., and Gravesen, S.:

Cladosporium herbarum Extract Characterized

by Means of Quantitative Immunoelectro-

phoretic Methods with Special Attention to

Immediate Type Allergy 1

Kristofferson, A.; Ahlstedt,S.; Pettersson,E., and

Svärd, P. O.: Antigens in Penicillin Allergy.

I. A Radioimmunoassay for Detection of Peni-

cilloylated Protein Contaminants in Penicillin

Preparations 13

Kristofferson, A.; Ahlstedt, S., and Svärd, P. O.:

Antigens in Penicillin Allergy. II. The Influ

ence of the Number of Penicilloyl Residues on

the Antigenicity of Macromolecules as Deter

mined by Radioimmunoassay (RIA), Passive

Cutaneous Anaphylaxis (PCA) and Antibody

Induction

23

Grimmer, 0.; Andersen, I.; Dale, S.; Oseid, S.;

Thorsdalen, N.; Skálhegg, B., and Aas, K.:

A New Well-Characterized, Purified Allergen

Preparation from Timothy Pollen. I. Chemical

Properties

29

Frostad, A. B.; Bolle, R.; Grimmer, 0., and Aas, K.: A New Well-Characterized, Purified Aller gen Preparation from Timothy Pollen. II. Allergenic in vivo and in vitro Properties

Grimmer, 0.; Bolle, R.; Frostad, A., and Aas, K.:

A New Well-Characterized, Purified Allergen

Preparation from Timothy Pollen. III. Im-

munological Properties in the Human Im-

munoglobulin E System

41

Nakagawa, T.; Kudo, K.; Okudaira, H.; Miyamoto, T., and Horiuchi, Y.: Characterization of the Allergenic Components of the House

Dust Mite, Dermatophagoides farinae

Jankovic, B. D.; Mitrovic, K.; Horvat, J., and

Mostarica, M.: Antigenic Correlations be

tween Chicken Brain Organelles, Thymocytes

and Bursacytes

54 
Takigawa, M.; Imamura, S., and Ofuji, S.: Dem onstration of Epidermis-Specific Heteroantigens in Thymic Epithelial Cells 58 Rham, O. de and Isliker, H.: Proteolysis of Bo vine Immunoglobulins 61 Sato, M.; Kasukawa, R.; Murai, T., and Yoshida, T.: A Solid-Phase Radioimmunoassay for $1 / 8 \mathrm{G}$ and IgM Antigammaglobulin Factor in Rheu matoid Arthritis Sera 70 Tsuji, M.; Hayashi, T.; Yamamoto, S.; Sakata, Y., and Toshida, T.: IgE-Type Antibodies to Ascaris Antigens in Man 78 Elwing, H.; Nilsson, L.-Å., and Ouchterlony, Ö.: A Precipitate Adsorption on Surface Tech nique: A Combination of Immunodiffusion and Thin-Layer Immunoassay 82 II. B- and T-Lymphocytes; Mast Cells Hoffmann-Fezer, G.; Rodt, H.; Götze, D., and Thierfelder, S.: Anatomical Distribution of T and B Lymphocytes Identified by Immunohistochemistry in the Chicken Spleen 86 Binns, R. M.; Pallares, V.; Symons, D. B. A., and Sibbons, P.: Effect of Thymectomy on Lymphocyte Subpopulations in the Pig. Demonstration of a Thymus-Dependent 'Null' Cell 96 Hallberg, A. and Hallberg, T.: Evolution of Three Lymphocyte Markers in Newborn, Preterm Infants 102

IV

Contents

Eremin, O.; Kraft, D.; Coombs, R. R. A.;

Franks, D.; Ashby, J., and Plumb, D.: Sur face Characteristics of the Human K (Killer) Lymphocyte

Manconi, P. E.: T Lymphocytes Bearing Recep tors for Fc of IgG in Guinea Pig Peritoneal Fluid. A Model for Human Extrahaematic Fluids Takigawa, M. and Hanaoka, M.: Role of T and Adherent Cells in in vitro Response of Nude Mouse Spleen Cells to Bacterial Lipopolysaccharide

Manski, W.; Whiteside, T. L., and Coll, J.: Metabolically Dependent and Independent Cell

Surface Antigens

Wybran, J.; Govaerts, A., and Fudenberg, H.: Differential Effect of Vinblastine and Colchi-cine on Human Active and Total T Rosettes 
Wallach, D. and Renoux, M.-L.: Rosette-For ming Mast Cells in Rat Anaphylaxis. Immunological Characteristics of Mast Cell Roset tes

III. Mediators of Allergic Reactions. Endogenous and Exogenous Stimulating or Suppressor Substances

Burrell, R. and Pokorney, D.: Mediators of Experimental Hypersensitivity Pneumonitis .... Jacobsson, H. and Blomgren, H.: Activated Mouse Lymphocyte Release Factors Which Modulate the Proliferative Response of Other Lymphocytes Petersson, B.-Å. and Stålenheim, G.: Enhance ment by a Serum Factor of ImmunoglobulinMediated Histamine Release from Human Leukocytes

Burger, M.: Stimulation of the in vitro Immune Response by Factors Present in the Human Serum

Patkar, S. A.; Kazimierczak, W., and Diamant, B.: Sodium Fluoride - a Stimulus for a Cal cium-Triggered Secretory Process Alonso-de Florida, F. and Del Castillo, A.: The in vitro Effects of Calcium and Potassium in Resensitization of Tracheal Smooth Muscles of the Allergized Guinea Pig Bernstein, I. L.; Vijay, H. M., and Perelmutter, L.: Non-Responder Basophils in Highly Rag weed-Sensitive Subjects Strannegård, 1.-L. and Strannegård, Ö.: Influence of Serum from Atopic Children on T Lympho cytes 217

Miller, F. and Habicht, G.S.: Serum-Derived

112 Immunosuppressive Substances. An Evaluation of Various Sources for an Endogenous Regulator of Lymphocyte Activation 228 Habicht, G.S. and Miller, F.: Serum-Derived 126 Immunosuppressive Substances. III. Regula tion of the Immune Response by Human Serum «-Globulin Fractions: the Dose-Re sponse Relationship 239

131 Ekramoddoullah, A. K. M.; Kisil, F. T., and Sehon, A. H.: Suppression of the IgE Antibody Response in Mice to Kentucky Blue 135 Grass Pollen Allergens 247 Bach, M. K. and Brashler, J. R.: On the Nature of the Presumed Receptor for IgE on Mast 148 Cells. IV. Inhibition of the PCA-Blocking Activity of Cell-Free Particulate Preparations 
and Intact Rat Peritoneal Mast Cells by In

hibitors of Proteases 255

152 Bice, D. E.; McCarron, K.; Hoffman, E. O., and Salvaggio, J.: Adjuvant Properties of Micropolyspora faeni 267

Ainapure, S. S.; Dhar, H. L., and West, G. B.:

The Insulin-Like Action of Bordetellapertussis

Vaccine in Rats

275

161 Jones, D. G. and Kay, A. B.: Chemotactic Activity of Guinea Pig Eosinophils for the ECF-A

Acidic Tetrapeptides, Histamine, Histamine Metabolites, and the Effect of HI- and H2-

170 Receptor Antagonists 277

Boyd, R. L.; Toh, B. H.; Muller, H. K., and Ward, H. A.: Actin-Like Protein in Chicken and

Mammalian Lymphoid Tissue Demon-

178 strated by Reactivity with Human Smooth

Muscle Autoantibody 283

Gill, T. J. Ill and Kunz, H. W.: Decreased Anti-

189 body Response following Immunization with

Enantiomorphic Synthetic Polypeptides .... 293 Lew, F. T.; Yukiyama, Y., and Osier, A. G.: Se-

193 rum Complement Changes in W/Fu Rats In-

oculated with Syngeneic (C58NT) D Lympho-

ma Cells 297

Keller, H. U.; Beck, E. A.; Hess, M. W., and

201 Cottier, H.: Significance of Hageman Factor

(Coagulation Factor XII) for Neutrophil Loco

motion and Chemotaxis 309

215 Ranadive, N. S. and Ruben, D. H.: The Effect of Phosphatidyl Serine on the Activation

Stage

Contents

$\mathrm{V}$

of Histamine Release Induced by Neutrophil

Cationic Protein 314

Hay, J. B.; Hobbs, B. B.; Johnston, M. G., and

Movat, H. Z.: The Role of Hyperemia in

Cellular Hypersensitivity Reactions 324

Nagasawa, K. and Mori, R.: Protection Against Experimental Allergic Encephalomyelitis in

Guinea Pigs by Bacterial Lipopolysaccharide 332

El-Azab, J. and Stewart, P. B.: The Difference in

Effect of Predosing with Antiallergic Com

pounds between the Rat PCA Model and the

Monkey Asthma Model. Comparison of the

Effects of PRD-92-Ea and Disodium Cromo-

glycate 343

El-Azab, J. and Stewart, P. B.: Pharmacologic

Profile of a New Antiallergic Compound PR D-

92-Ea 350 
Nelson, H. S.; Branch, L. B.; Raine, D.; Spaulding, H.; Black, J. W.; Pfeutze, B., and Wood, D.: jÇ-Adrenergic Subsensitivity Induced by

Chronic Administration of Terbutaline 362

Cheng-po Sung; Saunders, H. L.; Krell, R. D., and Chakrin, L. W.: Studies on the Mecha nism of Tachyphylaxis to Disodium Cromoglycate 374

Cheng-po Sung; Saunders, H. L.; Lenhardt, E., and Chakrin, L. W.: Further Studies on the Tachyphylaxis to DSCG. The Effect of Con centration and Temperature 385

Talbott, M. W. and Strausser, H. R.: Increase in the Severity of Allergic-Type Bronchospasm in Sensitized and Challenged Cats Treated with Cortisone 395

Ahlstedt, S. and Eriksson, N. E.: Immunotherapy in Atopic Allergy - Antibody Titres and Avidities during Hyposensitization with Birch and Timothy Pollen Allergens $\quad 400$ IV. Autoallergic States. Tumor Immunology Malavé, T. and Cuadra, C.: Impaired Function of Peripheral Lymphocytes in Systemic Lupus Erythematosus 412

Bennett, W. M.; Bardana, E. J.; Houghton, D. C; Pirofsky, B., and Striker, G. D.: Silent Renal Involvement in Systemic Lupus Ery thematosus $\quad 420$

Romagnani, S.; Amadori, A.; Maggi, E.; Biagiotti, R., and Ricci, M.: Study of some Immunological Parameters in Untreated Patients with Hodgkin's Disease 429

Rubinstein, E.; Sokal, J. E.; Reisman, R. E., and Arbesman, C. E.: Relationship of Serum Total IgE and Cell-Mediated Immunity in Patients with Hodgkin's Disease 439 Molinari, J. A. and Ebersole, J. L.: Antineoplastic Effects of Long-Term Trichinella spiraiis In fection on B-16 Melanoma 444 Molinari, J. A. and Ebersole, J. L.: In vitro Re sponses of Spleen Cells from Trichinella spi $\mathrm{ral}^{1} / 8$-Infected Mice 449 V. Infection and Immunity Sohl Åkerlund, A.; Ahlstedt, S.; Hanson, L. Å.; Lindberg, U., and Oiling, S.: Differences in Antigenicity of Escherichia coli Strains Isolat 
ed from Patients with Various Forms of

Urinary Tract Infections $\quad 458$

Ridell, M.: Studies on Corynebacterial Precipiti-

nogens Common to Mycobacteria, Nocardiae

and Rhodochrous $\quad 468$

Kumar, V.; Klingman, J. D., and Wicher, K.:

Host Response to Treponema pailidum Infec

tion. I. Quantitative Changes of Lipids in

Rabbit Organs 476

Wicher, V. and Wicher, K.: Host Response to

Treponema pailidum Infection. II. Rabbit

Leukocyte Migration Inhibition in the Presen

ce of Homologous Organ Extracts 481

Merino, F.; Ajjam, E.; Hernandez, A.; Dawido-

wicz, K., and Merino, E. J.: In vitro Infection

of Murine Macrophage by Leishmania brasi-

liensis. Mechanism of Penetration 487

Cypess, R. H.; Ebersole, J. L., and Molinari, J.

A.: Specific Antibody Levels in the Intestinal

Perfusates of Heligosomoides polygyrus-lniect-

ed Mice 496

Isaak, D. D.; Jacobson, R. H., and Reed, N. D.:

The Course of Hymenolepis nana Infections in

Thymus-Deficient Mice 504

VI. Miscellaneous Topics

Løwenstein, H.; Krasilnikoff, P. A.; Bjerrum,

O. J., and Gudmand-Høyer, E.: Occurrence of

Specific Precipitins against Bovine Whey Pro

teins in Serum from Children with Gastro

intestinal Disorders 514

Hanson, D. G.; Vaz, N. M.; Maia, L. C. S.;

Hornbrook, M. M.; Lynch, J. M., and Roy,

C. A.: Inhibition of Specific Immune Re

sponses by Feeding Protein Antigens

VI

Contents

Yoo, T. J.; Kuo, C. Y., and Joseph, S.: Reaginic West, G. B.: Anaphylactoid Responses in Rats 542

Immune Response to Tree Pollen Antigen in Shin, D. H.; Becker, B., and Bell, C. E.: HLA in LBN Rats 533 Primary Open-Angle Glaucoma 546

Virella, G.; Slappendel, R. J., and Goudswaard, J.: Multiple Myeloma, IgA Cryoglobuline- Author-Index 551

mia and Serum Hyperviscosity in a Dog . . . 537 